\title{
Longevity and Mortality in 15 Rodent Species and Subspecies Maintained in Laboratory Colonies ${ }^{1}$
}

\author{
Peter MORRISON, Robert DIETERICH \& Diane PRESTON
}

\begin{abstract}
Morrison P., Dieterich R. \& Preston D., 1977: Longevity and mortality in 15 rodent species and subspecies maintained in laboratory colonies. Acta theriol., 22. 23: 317-335 [With 5 Tables \& 9 Figs.].

Longevity/mortality data are presented for 15 wild rodent taxa as maintained in laboratory colonies: Microtus pennsylvanicus tananaensis, $M$. oeconomus macfarlani, $M$. o. operarius, $M$. miurus, $M$. abbreviatus, Lemmus lemmus, L. sibiricus trimucronatus, Dicrostonyx stevensoni, Clethrionomys rutilus, Peromyscus maniculatus borealis, $P$. m. bairdii, Baiomys taylori, Calomys ducilla, C. callosus and Acomys cahirinus. Infant mortality (1st week) averaged 11 percent ( 0 to $23 \%$ ) and infant + juvenile mortality (1st month) averaged 23 percent (10 to $38 \%$ ). Median life spans for animals weaned at 1 month averaged 50 wk and ranged from 25 to $L$. $s$. to $108 \mathrm{wk}$ in $A$. $c$. The range was 25 to $40 \mathrm{wk}$ in microtines and 44 to $105 \mathrm{wk}$ in the cricetines excluding $B$. $t$. Most microtine survival curves were linear or woblique $(d S / d t=-k)$ rather than logarithmic $(d \dot{S} / S d t=-k)$ or Gompertzian $(\log d S / S d t=A=k t)$ and could be characterized by 2 constants describing a linear increase in mortality with time: $d S / S d t=-k\left(t=t^{\circ}\right)$ or 2 in $S / S_{0}=-k$ $\left(t+t^{\circ}\right)^{2}$. Unmated $B$. $t$. showed logarithmic survival which, on regrouping into successful breeding pairs, changed to $1 / 3$ the rate and a linear configuration. Other species showed much smaller effects of grouping or of sex on survival. Early mortality in $M$. o. m., L. l. and L. s. was correlated with an early incidence of fatty livers and in $D$. s., of respiratory pathology.
\end{abstract}

[Inst. Arctic Biol., Univ. Alaska, Fairbanks, Ak 99701, USA]

\section{INTRODUCTION}

'The life spans of mammals vary enormously ranging from a few weeks to scores of years. A considerable portion of this variation can be related to size as an intrinsic property of any species and, among morphological and physiological characters, brain weight and metabolic rate have been suggested as functionally correlated with potential longevity or maximum life span (S a che r, 1959). Besides such intrinsic factors, various environmental influences can increase mortality in natural populations. Survival curves (survivors, $S$. vs time or life span,

1 This work was supported in part by The Animal Resources Branch, National Institute of Health (grant RR 00518). 
t) dominated by environmental influences are quite different from those of protected animals and ideal or limiting forms for the respective types have been suggested as exponential with constant mortality $(d S / S d t=$ $-k$ ) and "rectangular « with zero or minimum mortality through most of the life $\operatorname{span}(t=k \pm \sigma)$. D e e v e y (1947) used various birds and the Dall sheep as examples of these respective limiting types. Conditions of captivity can decrease mortality in wild species to yield intermediate linear or »oblique" survival curves $(d S / d T=-k)$ (C o m f or t, 1957a, 1964) but limited data are available for such populations.

During the development and productive use of captive colonies of a series of wild rodent species (M or ris on, 1971; D i e te rich, 1974), data sets on their respective mortality/longevity have been accumulated. The present study presents and compares these data which provide useful base lines for ongoing production, and allow the identification of different mortality patterns and the comparison of different species for selection.

\section{MATERIAL AND METHODS}

The fifteen taxa used in this study were among the standarized animal colonies maintained at the Institute of Arctic Biology. The species used, their vernacular names, geographical origins and diets are listed in Table 1. Except for the old world Acomys cahirinus, a murid, all belong to the family Cricetidae, nine being from the characteristically northern subfamily Microtinae and the remaining five from the subfamily Cricetinae with its more characteristically temperate and subtropical distribution.

These rodents were born in captivity and maintained under continuous standard conditions of $20^{\circ} \mathrm{C}, 16 \mathrm{hr}$ of artificial light and eight $\mathrm{hr}$ of darkness in $8^{\prime \prime} \times 8^{\prime \prime} \times$ $\times 36^{\prime \prime}$ fiberglass boxes with expanded metal covers (M o r r is on, 1960). Bedding of wood shavings and nesting material of facial tissues was changed weekly. Water and food were available ad libitum. The animals were weaned at three to four weeks as sibling groups of the same sex. Rodents were paired for breeding at a minimum age of two months. Animals not paired were continued in their original groupings.

The colony was under the supervision of a veterinarian and conventional practice and precautions were maintained. Access to the animals was restricted but not prohibited. New animals were maintained under quarantine before joining the colony. Gross and microscopic examination of dead or dying individuals was carried out by an experienced veterinary pathologist (Table 2). Except for Dicrostony $x$ which showed unusual susceptibility among our species, the pathologic data do not show infectious disease as a preponderant cause of death. Pulmonary + bacterial mycosis + middle ear infection together amounted to 23 percent of the observed pathology and pulmonary lesions may represent secondary rather than primary involvement. No epidemic losses occured during these studies. Serum was tested periodically for evidence of a number of common murine pathogens: reo virus, Sendai virus, ectromelia (mousepox), mouse hepatitis virus, lymphocytic choriomeningitis and Theiler's mouse encephalomyelitis. The only positive reactions 
Table 1

Identification and diets of Rodent subjects.

\begin{tabular}{|c|c|c|c|}
\hline Species ${ }^{1}$ & Common name & Geographical origin & Diet supplement 2 \\
\hline Microtus pennsylvanicus tananaensis & Meadow vole & Cent. AK. & Barley sprouts \\
\hline Microtus oeconomus macfarlani & Tundra vole & E. AK. + Yukon + NWT & $" \quad " \quad$ \\
\hline Microtus eocenomus operarius & Tundra vole & W. AK. & " \\
\hline Microtus miurus muriei & Singing vole & $\begin{array}{l}\text { Brooks Range to } \mathrm{W} . \\
\text { Coast AK. }\end{array}$ & $" \quad "$ \\
\hline Microtus abbreviatus (a) & Insular vole & St. Matthew I., AK. & $\begin{array}{l}\text { Sunflower seeds, carrots \& } \\
\text { sprouts }\end{array}$ \\
\hline Lemmus lemmus (b) & Norwegian lemming & Norway & Carrots \& sprouts \\
\hline Lemmus sibiricus trimucronatus & Brown lemming & Arctic Coast AK. & 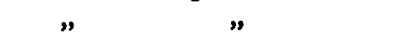 \\
\hline Dicrostonyx stevensoni $(a)$ & Collared lemming & Umnak I., AK. & $"$ \\
\hline Clethrionomys rutilus & Red-backed vole & AK. \& N. Canada & None \\
\hline Peromyscus maniculatus borealis (e) & Deer mouse & N. W. Canada & Sunflower seeds \\
\hline Peromyscus maniculatus bairdii (d) & Deer mouse & Mid. W. U. S. & $" \quad$, \\
\hline Baiomys taylori $(e)$ & Pygmy mouse & Coastal Texas \& Mexico & $"$ \\
\hline Calomys ducilla $(f)$ & Vesper mouse & Andes, Peru & $"$ \\
\hline Calomys callosus $(g)$ & Laucha de campo & Lowland Bolivia & $" \quad " \quad$ \\
\hline Acomys cahirinus $(h)$ & Egyptian spiny mouse & Egypt \& Near East & $\begin{array}{l}\text { Carrots, orange \& } \\
\text { sunflower seeds }\end{array}$ \\
\hline
\end{tabular}

1 Original stocks of these rodents were obtained through the kindness of (a) Dr. R. Rausch, Arctic Health Research Center, Fairbanks; (b) Dr. E. Ostbye, Univ. Oslo, Blindern; (c) Dr. W. Fuller, Univ. Alberta, Edmonton; (d) Dr. R. Reeder, Univ. Wisconsin, Madison; (e) Dr. J. Hudson, Rice University, Houston; (f) Dr. O. P. Pearson, Univ. California, Berkeley (=C. lepidus ducillus); (g) Dr. K. M. Johnson, USPHS, NIAID, Middle America Research Heights, CZ (Pearson and Patton, 1976, have recently referred these animals to C. fecundus on the basis of chromosome morphology.); (h) National Zoological Park, Washington.

2 Basic diet for all animals was Mouse Breeder Chow (Ralson Purina Co.), wheat germ, and rolled oats; except lemmings who received rabbit pellets instead of chow. 
were to reo III virus (11/86 in three species) but no symptoms of active infection could be found.

Population losses were of three kinds: (1) withdrawal for sacrifice or other experimental use $(44 \%)$, (2) other artificial loss as by escape or failure of the water supply $(5 \%)$ and (3) "natural " loss. The natural loss $(\Delta S / S)$ was referred to the number of individuals beginning that month and these values were used to construct corrected survival tables for natural attrition alone (Table 3). A more precise form uses the average population at risk during the month or even computes on a day-to-day basis (St or e r, 1962). However, such correction factors for table 2 would only average 1.10 for monthly mortality and 0.87 for survivors at $10 \mathrm{mo}$, and the forms of the mortality and survival curves would not be changed. Since early losses are of a different character than later losses, they have been excluded in most of the graphical comparisons which use the number of animals weaned at one month as the base.

Table 2

Pathological lesions grouped according to diagnostic category ${ }^{1}$.

\begin{tabular}{|c|c|c|c|c|c|c|c|c|c|c|c|c|c|c|c|c|}
\hline Species & $\mathrm{N}$ & 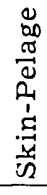 & 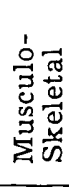 & 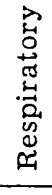 & 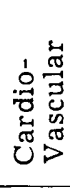 & 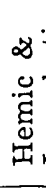 & 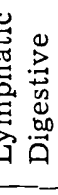 & 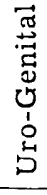 & 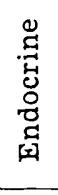 & 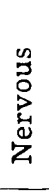 & 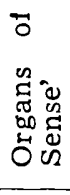 & : & 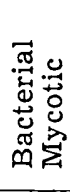 & 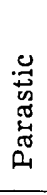 & 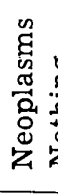 & 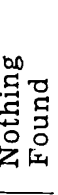 \\
\hline M. penn.ten. & 27 & & 1 & 9 & & & 3 & 11 & & & & 2 & & 1 & & 11 \\
\hline M. oec. mac. & 50 & 1 & & 13 & 3 & 1 & 24 & 14 & & & & 10 & 1 & & & \\
\hline M. o & 12 & & & 1 & & 1 & 1 & & & & 1 & 3 & & 1 & 1 & 5 \\
\hline Lemmus lemmus & 15 & & & 4 & & & 6 & 3 & & & 1 & 2 & 1 & & 2 & 3 \\
\hline Lemmus sib. tri. & 44 & 1 & 2 & 10 & 1 & & 26 & 16 & 1 & & 2 & 8 & 2 & 1 & & 4 \\
\hline ensoni & 95 & 1 & 1 & 41 & 3 & 4 & 17 & 27 & & 3 & 22 & 7 & 4 & & 9 & 19 \\
\hline C. rutilus & 26 & 1 & & 7 & & & 7 & 8 & & & & 2 & & & 2 & 8 \\
\hline Calomys ducilla & 10 & 1 & & 4 & & 1 & 5 & 3 & & & & 3 & & & 2 & 1 \\
\hline Calomys callo & 25 & 1 & 1 & 7 & 1 & 1 & & 7 & 1 & 2 & 1 & 6 & 2 & 1 & 1 & 9 \\
\hline Acomys cahirinus & 17 & & & 3 & & & 1 & 5 & & & & 2 & & & & 8 \\
\hline Total & 321 & 6 & 5 & 99 & 8 & 8 & 90 & 96 & 2 & $\mathbf{5}$ & 27 & 45 & 10 & 4 & 17 & 76 \\
\hline
\end{tabular}

1 Observations by R. Dieterich and R. Van Pelt

2 Includes cannibalism, malnutrition, stress, dehydration, toxemia

Other descriptive studies on these maintained populations include aspects of productivity (Morrison et al., 1976a), growth (Mor rison et al., 1976b), organ weights (Dieterich et al., 1973), biochemistry (Galster \& Morrison, 1974) and physiology (Rose nmann \& Morrison, 1974).

\section{RESULTS}

Basic survival data for the 15 taxa are given in Table 4 in relation to the total number of young identified after birth which averaged more than 300 and ranged from 200 to 670 in different groups. Values at one week defined infant or neonatal mortality which averaged 11 percent and ranged from 0 in the two species of Calomys to 23 percent in $M i$ - 
crotus pennsylvanicus and $M$. oeconomus macfarlani. Values at 1 month included an additional juvenile loss and averaged 23 percent in the different groups ranging from 10 percent in Calomys callosus to 38 percent in Lemmus sibiricus.

Figure 1 plots survivors against time for several representative groups. Without commitment to any particular function, these points can be

Table 3

Representative mortality table: Microtus oeconomys macfarlani.

\begin{tabular}{|c|c|c|c|c|c|c|c|c|}
\hline \multirow[b]{2}{*}{ 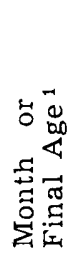 } & \multirow[b]{2}{*}{ 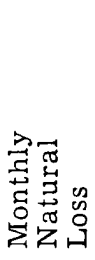 } & \multirow[b]{2}{*}{ 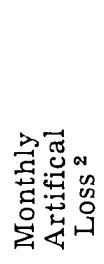 } & \multirow[b]{2}{*}{ 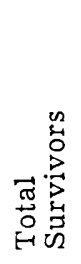 } & \multirow[b]{2}{*}{ 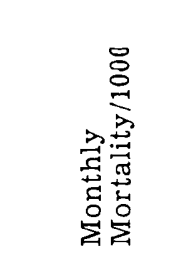 } & \multirow[b]{2}{*}{ 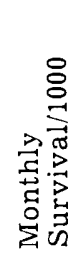 } & \multicolumn{3}{|c|}{ Corrected Total Survivors } \\
\hline & & & & & & 总高 & 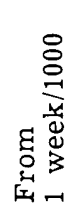 & 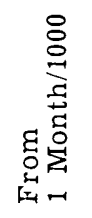 \\
\hline 0 & & & 671 & & & 1000 & & \\
\hline $1 / 4$ & 151 & 0 & 520 & $151 / 671=210$ & & 775 & 1000 & \\
\hline 1 & 62 & 15 & 443 & $62 / 520=119$ & $(881)$ & 683 & 881 & 1000 \\
\hline 2 & 42 & 75 & 326 & $42 / 443=95$ & 905 & 618 & 797 & 905 \\
\hline 3 & 37 & 54 & 235 & $37 / 326=113$ & 887 & 548 & 707 & 803 \\
\hline 4 & 21 & 28 & 186 & $21 / 235=89$ & 911 & 499 & 644 & 732 \\
\hline 5 & 22 & 7 & 157 & $22 / 186=105$ & 882 & 440 & 568 & 645 \\
\hline 6 & 17 & 5 & 137 & $17 / 157=108$ & 892 & 393 & 507 & 576 \\
\hline 7 & 15 & 10 & 110 & $15 / 137=111$ & 889 & 349 & 450 & 511 \\
\hline 8 & 8 & 12 & 90 & $8 / 110=73$ & 927 & 324 & 418 & 475 \\
\hline 9 & 16 & 5 & 69 & $16 / 90=178$ & 822 & 266 & 343 & 390 \\
\hline 10 & 11 & 1 & 57 & $11 / 69=159$ & 841 & 224 & 289 & 328 \\
\hline 11 & 12 & 3 & 42 & $12 / 57=210$ & 790 & 177 & 228 & 259 \\
\hline 12 & 10 & 2 & 30 & $10 / 42=238$ & 762 & 135 & 174 & 198 \\
\hline 13 & 5 & 6 & 19 & $5 / 30=167$ & 833 & 112 & 145 & 165 \\
\hline 14 & 1 & 4 & 14 & $1 / 19=53$ & 947 & 106 & 137 & 156 \\
\hline 15 & 5 & 0 & 9 & $5 / 14=356$ & 643 & 68 & 88 & 100 \\
\hline 16 & 2 & 0 & 7 & $2 / \quad 9=222$ & 778 & 53 & 69 & 78 \\
\hline 17 & 1 & 0 & 6 & $1 / \quad 7=143$ & 857 & 46 & 59 & 67 \\
\hline 18 & 2 & 1 & 3 & $2 / 6=333$ & 667 & 30 & 39 & 44 \\
\hline 19 & 2 & 0 & 1 & $2 / 3=667$ & 333 & 10 & 13 & 15 \\
\hline 24 & 1 & 0 & 0 & & 0 & 0 & 0 & 0 \\
\hline
\end{tabular}

1 Periods are lunar months of 28 days. 2 Animals withdrawn for experimental use were selected for age only.

represented by one or more linear segments and figure 2 compares such linear representations for all the taxa. Survival curves for species and subspecies of Microtus (Fig. 2A) characteristically showed a single rate over the first $80 \%$ of loss followed by a much slower rate of loss over the remaining 20 percent. Curves for the lemmings (Fig. 2B) showed three segments, an initial phase through 60 percent of loss, a slower rate during the next 30 percent and a still slower rate for the final 10 percent. The curves for non-microtine species (Fig. 2C) are more diverse. 
Table 4

Survivors per thousand from initial populations of 15 rodent species and subspecies.

\begin{tabular}{|c|c|c|c|c|c|c|c|c|c|c|c|c|c|c|c|}
\hline \multirow{3}{*}{$\begin{array}{l}\text { Age in } \\
\text { weeks }\end{array}$} & \multirow{3}{*}{$\begin{array}{l}M . p \cdot t \\
411\end{array}$} & \multirow{3}{*}{$\begin{array}{l}\text { M.o.m. } \\
520\end{array}$} & \multirow{3}{*}{$\begin{array}{c}\text { M. } 0.0 \\
198\end{array}$} & \multirow{3}{*}{$\begin{array}{l}\text { M.m. } \\
341\end{array}$} & \multicolumn{5}{|c|}{ Species and Initial numbers ${ }^{1 /}$} & \multirow{3}{*}{$\begin{array}{c}\text { P.m.bo. } \\
315\end{array}$} & \multirow{3}{*}{$\begin{array}{c}\text { P.m.ba. } \\
226\end{array}$} & \multirow{3}{*}{$\begin{array}{l}\text { B.t. } \\
393\end{array}$} & \multirow{3}{*}{$\begin{array}{l}\text { c.d. } \\
393\end{array}$} & \multirow{3}{*}{$\begin{array}{l}\mathrm{C} . \mathrm{c} . \\
197\end{array}$} & \multirow{3}{*}{$\begin{array}{l}\text { A.C. } \\
196\end{array}$} \\
\hline & & & & & H.a. & L.1. & L.s. & D.s. & $\mathrm{C} . \boldsymbol{r}$ & & & & & & \\
\hline & & & & & 247 & 323 & 291 & 390 & 399 & & & & & & \\
\hline $1^{2 /}$ & 769 & 775 & 820 & 840 & 877 & 917 & 847 & 840 & 885 & 909 & 980 & 952 & 999 & 999 & 385 \\
\hline $4^{3 /}$ & 715 & 683 & 634 & 754 & 763 & 752 & 620 & 761 & 774 & 840 & 864 & 805 & 893 & 899 & 872 \\
\hline 8 & 705 & 618 & 625 & 703 & 731 & 648 & 541 & 717 & 712 & 811 & 833 & 734 & 773 & 828 & 862 \\
\hline 12 & 689 & 548 & 612 & 664 & 713 & 574 & 478 & 646 & 667 & 789 & 775 & 624 & 696 & 312 & 852 \\
\hline 16 & 658 & 499 & 607 & 615 & 685 & 547 & 433 & 578 & 650 & 754 & 756 & 560 & 667 & 730 & \\
\hline 20 & 632 & 440 & 548 & 570 & 647 & 480 & 384 & 539 & 600 & 729 & 740 & 516 & 636 & 703 & 329 \\
\hline 24 & 582 & 393 & 507 & 525 & 617 & 436 & 347 & 498 & 581 & 649 & 703 & 465 & 613 & 686 & 323 \\
\hline 28 & 531 & 349 & 473 & 489 & 582 & 373 & 252 & 450 & 514 & & 674 & 393 & 596 & 649 & 816 \\
\hline 32 & 512 & 324 & 450 & 416 & 554 & 318 & 224 & 402 & 458 & 639 & 656 & 357 & 569 & 608 & 752 \\
\hline 36 & 469 & 266 & 402 & 343 & 510 & 292 & 194 & 378 & 424 & 623 & 628 & 317 & 538 & 543 & \\
\hline 40 & 437 & 224 & 338 & 269 & 486 & 283 & 146 & 365 & 387 & 587 & 622 & $28 \epsilon$ & 518 & 515 & 732 \\
\hline 44 & 415 & 177 & 327 & 190 & 455 & 244 & 134 & 329 & 360 & 581 & 614 & 260 & 495 & 504 & 701 \\
\hline 48 & 383 & 135 & 303 & 179 & 415 & 204 & 105 & 305 & 334 & 567 & 606 & 243 & 486 & 470 & 680 \\
\hline 52 & 342 & 112 & & 141 & 362 & 150 & 87 & 285 & 298 & 515 & 598 & 221 & 476 & & 669 \\
\hline 56 & 295 & 106 & 261 & 113 & 311 & 119 & 69 & 245 & 281 & 493 & & 214 & 445 & & 264 \\
\hline 60 & 264 & 68 & 188 & 108 & 284 & 86 & & 203 & 262 & 460 & & 211 & 434 & 457 & 647 \\
\hline 64 & 253 & 53 & 174 & 68 & 250 & 66 & 56 & 198 & 243 & 452 & 569 & 203 & 410 & 443 & $60 \%$ \\
\hline 58 & 217 & 46 & & 63 & 225 & 49 & & 161 & & 424 & & 199 & 374 & 413 & 590 \\
\hline 72 & 176 & 30 & 144 & 50 & 169 & & 44 & 120 & 223 & & & 196 & 349 & 375 & \\
\hline $7 \epsilon$ & & 10 & 108 & 36 & 142 & 32 & 31 & 107 & 182 & 401 & 556 & $\uparrow 75$ & 335 & 307 & 579 \\
\hline 80 & 160 & & 90 & 22 & 99 & 24 & & 99 & 160 & 378 & & 158 & 306 & 239 & \\
\hline 84 & & & 23 & & & 8 & 25 & 84 & & 353 & 541 & 131 & 291 & 153 & 567 \\
\hline 88 & & & & & 76 & 0 & 19 & 54 & 137 & 327 & & 120 & 230 & 134 & 556 \\
\hline 92 & 107 & & & & 54 & & 13 & 45 & 91 & 314 & 525 & :O9 & 212 & 77 & 432 \\
\hline 96 & & 0 & & & 45 & & 6 & & 61 & 300 & 492 & 103 & & 57 & 505 \\
\hline 100 & & & 0 & & & & & 23 & 30 & $27 \hat{z}$ & $47 \varepsilon$ & 34 & 185 & & 479 \\
\hline 104 & 71 & & & & 27 & & & & 0 & & 430 & & & & 451 \\
\hline 108 & & & & & 13 & & & & & 257 & 410 & 80 & 124 & & 437 \\
\hline 112 & & & & 0 & & & 0 & 11 & & $24 \hat{C}$ & 389 & 69 & & & \\
\hline 116 & & & & & & & & & & & & 6.3 & 82 & & 387 \\
\hline 120 & & & & & 0 & & & & & & & 50 & & & 370 \\
\hline 124 & 0 & & & & & & & & & 194 & 359 & 44 & & & 353 \\
\hline 128 & & & & & & & & 0 & & 161 & & 36 & 41 & & 335 \\
\hline 132 & & & & & & & & & & 144 & 320 & 30 & & & 301 \\
\hline 136 & & & & & & & & & & & & 22 & & & 282 \\
\hline 140 & & & & & & & & & & 125 & & & & & \\
\hline 144 & & & & & & & & & & $/ 83$ & & 11 & 0 & & \\
\hline
\end{tabular}

1 At 1 week; for species coding refer to table 1 .

21 -week values defines infant (neonatal) mortality.

3 -week value defines infant + juvenile mortality. 


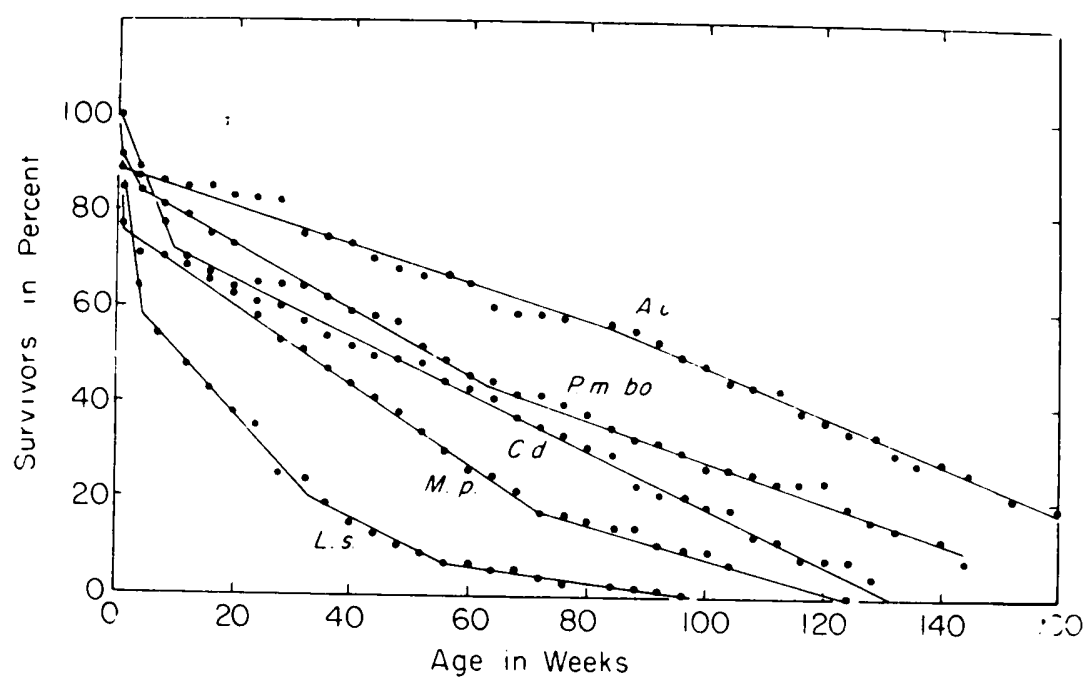

Fig. 1. Representative survival with data points fitted to linear segments by inspection. For species coding refer to Table 1

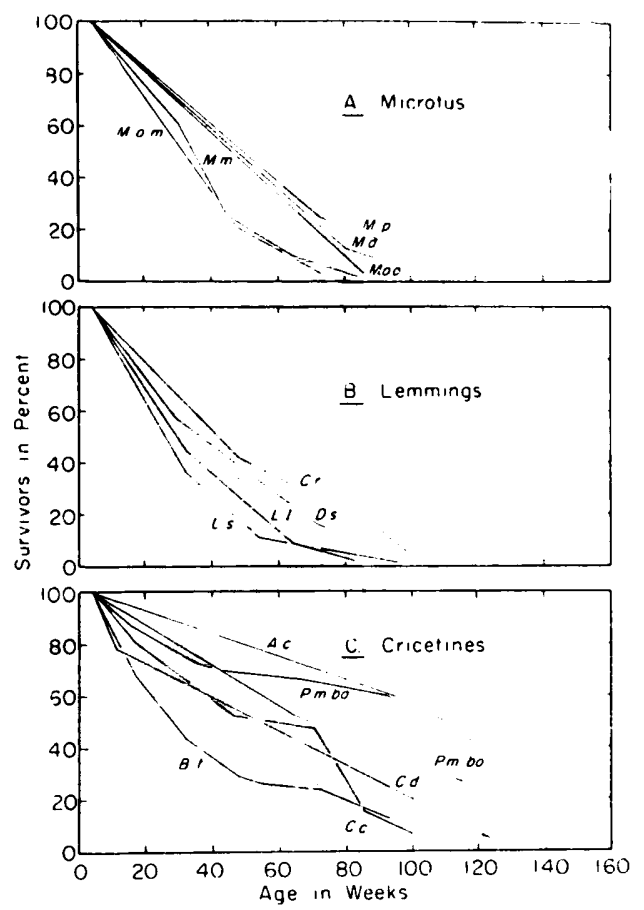

Fig. 2. Survival curves for all species by groups. (A) Microtus, (B) lemmings and Clethrionomys, (C) cricetines and Acomys. For species coding refer to Table 1. 
Losses in Calomys ducilla are described (last 80 percent) by a single linear constant $\left(0.65 \% S_{0} / w k\right)$. In Peromyscus and Acomys which showed the greatest longevity with initial losses of $<1 \% S_{0} / w k$, the survival curves also showed little reduction in rate during later stages but P. m. bairdii showed a notable interim reduction between 40 and 90 weeks of age. Baiomys and $C$. callosus also showed bimodal curves with reduced mortality from 50 to 70 weeks.

Several time constants for the various curves are given in Table 5 . The median life span $\left(t_{50}\right)$ with values ranging from 23 to 120 weeks is a useful single index of survival under given experimental or natural

Table 5

Rate and time constants for rodent survival curves.

\begin{tabular}{|c|c|c|c|c|c|c|c|c|}
\hline Species & $\begin{array}{l}t_{50}{ }^{1} \\
\text { wk }\end{array}$ & $\begin{array}{l}t_{\max }^{2} \\
\mathrm{wk}\end{array}$ & $\begin{array}{l}t_{90}{ }^{8} \\
\text { wk }\end{array}$ & $\begin{array}{l}\text { c.v. }{ }^{4} \\
\%\end{array}$ & $\begin{array}{r}k_{1}^{5} \\
\% / \mathrm{wk}\end{array}$ & $\begin{array}{r}t^{\circ} \\
\mathrm{wk}\end{array}$ & $\begin{array}{c}k^{6} \\
\times 10^{4} / \mathrm{wk}\end{array}$ & $\begin{array}{c}k^{5} \\
0 / \% / w k=\end{array}$ \\
\hline Microtus pennsylvanicus & 50 & 124 & 104 & 66 & & 4 & 4.8 & 2.6 \\
\hline Microtus o. macfarlani & 31 & 96 & 60 & 60 & & 12 & 8.9 & \\
\hline Microtus o. operarius & 47 & 100 & 82 & 58 & & 0 & 6.2 & \\
\hline Microtus abbreviatus & 48 & 120 & 88 & 60 & & 4 & 5.2 & \\
\hline Microtus miurus & 43 & 112 & 62 & 66 & & 4 & 10.0 & \\
\hline Lemmus lemmus & 30 & 88 & 64 & 67 & & 16 & 7.7 & \\
\hline Lemmus sibiricus & 26 & 96 & 64 & 72 & & 16 & 10.0 & 4.0 \\
\hline Dicrostonyx stevensoni & 37 & 128 & 86 & 73 & $2.0^{8}$ & -4 & 5.2 & \\
\hline Clethrionomys rutilus & 40 & 104 & 94 & 70 & $1.8^{9}$ & & & \\
\hline Baiomys taylori & 23 & 170 & 108 & 92 & 3.2 & & & \\
\hline Peromyscus $m$. borealis & 70 & $>160$ & 160 & 69 & 1.0 & & 1.1 & \\
\hline Peromyscus $m$. bairdii & $105^{7}$ & & $>160$ & & 1.0 & & 0.3 & \\
\hline Calomys ducilla & 60 & 160 & 114 & 77 & 1.0 & -32 & 4.2 & \\
\hline Calomys callosus & $(52)$ & $>101$ & 90 & 69 & 1.6 & & 6.5 & \\
\hline Acomys cahirinus & 110 & & $>160$ & & & 12 & 1.2 & \\
\hline
\end{tabular}

1 Median life span.

2 Maximum observed life spans are lower than might be expected because of continuing experimental use of individuals.

3 Survival time to last decile (90th percentile).

4 Coefficient of variation, $100 \sigma t / t$

$5 d S / S d t=-k$ or $\ln S / S_{o}=-k t$

${ }^{6} d S / S d t=-k\left(t+t^{\circ}\right)$ or $\ln S / S_{o}=-k\left(t+t^{\circ}\right)^{2}$

$7 \mathrm{Sacher} \& \mathrm{Staffeldt}$ (1972) show a value of $170 \mathrm{wk}$ for P. leucopus.

${ }^{3}$ Data from M a n ning (1954) give a value $>1.7 \%$ wk for $D$. groenlandicus.

9 Data from B u chalczyk (1970) also give a value of $1.8 \%$ a/wk for C. glareolus.

conditions. The maximum life span ( $\left.t_{\max }\right)$ is another common index used as a measure of the potential or intrinsic longevity of the species (S a cher, 1959), but our values are lower than might be expected because of continuing experimental use of older individuals. As a limit, $t_{\max }$ is intrinsically more variable than a mean and $\mathrm{Com}$ for $\mathrm{t}$ (1959) has used the survival time for the last decile $\left(t_{90}\right)$ as a measure of life span. Also given in Table 5 are values for the coefficient of variation, a common statistic which may be a useful index of the general form of 
the survival curve including environmental influences together with genetic variability and any intrinsic variability of the mortality process (S a c h e r, 1956). Limiting values might range from near zero for a »rectangular" curve $(t=k \pm \sigma)$, to near one half for a linear curve, to near one for an exponential curve $(d S / S d t=-k)$ or greater than one for forms in which mortality decreases with time $(d S / S d t=f(1 / t))$. Actual values range from 0.20 in strains of laboratory mice (S torer, 1966) and 0.24 in the grasshopper mouse (O'F a r r e l l, 1975) in captivity to $1.1-1.4$ in several heteromyid rodents in nature $(\mathrm{F} \mathrm{re} \mathrm{ch}$ et al., 1967). In our series the coefficient of variation was lowest in $M$. o. operarius (0.58) and highest in Baiomys (0.92).

The curve for the pigmy mouse Baiomys appeared bimodal so the data were examined more closely by separately plotting deaths for reproducing and non-reproducing, males and females. The sexes did not differ but segregation as successful breeding pairs reduced the loss rate by a

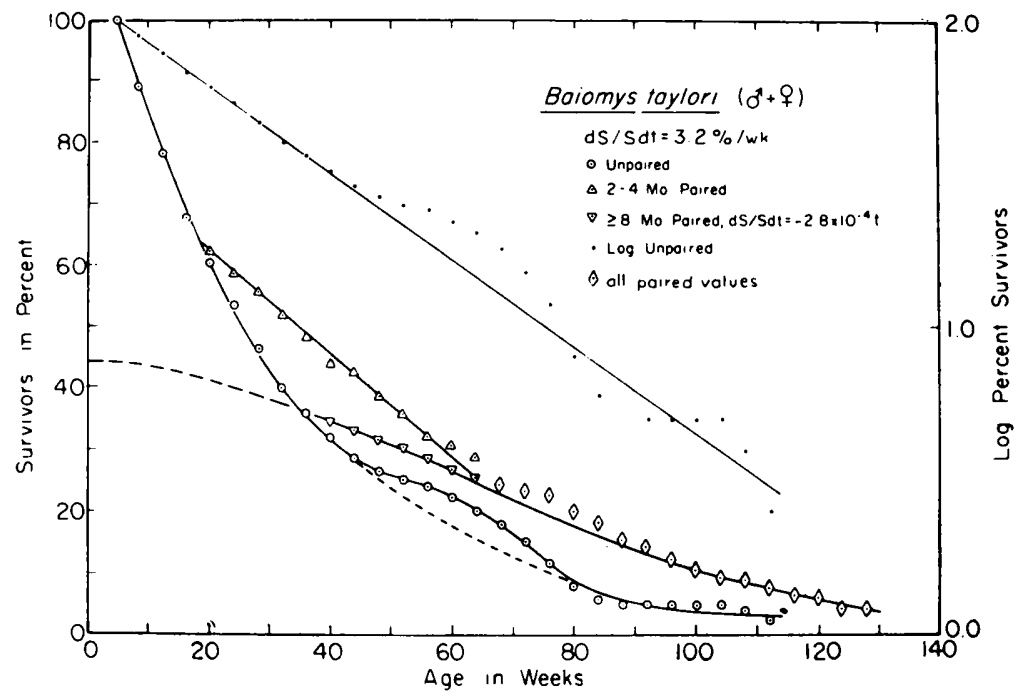

Fig. 3. Survival curves for Baiomys taylori (moving-3 averages).

factor of 3 (Figure 3) and changed the form from a logarithmic to a linear configuration. Thus Baiomys kept singly or in groups of the same sex after weaning through the 12 th week showed much higher mortality before pairing, a higher mortality that was continued in the non-reproducing group through the following weeks. The survival curves for discrete groups paired at $8-16$ and at $32-40$ weeks showed a similar loss rate below $25 \% S_{0}$ perhaps suggesting a resistant component in the population. The losses for unpaired Baiomys followed an exponential curve with $d S / S d t=3.2 \% / \mathrm{wk}$. 
Separate analysis by sex and pairing showed a small advantage of pairing in $M$. abbreviatus with the curves displaced by +10 wk or $+13 \% S_{0}(40-80 \mathrm{wk})$ and a similar advantage for males over females (Figure 4). In Clethrionomys the curve for females was similarly displaced by $+10 \mathrm{wk}$ or $+19 \%$ from that for males (Figure 4 ). The response in Dicrostonyx was less clear-cut since at 1 year there was no difference in survival between the four groups (paired and unpaired, males and females). During the first year paired animals and females had a ternporary advantage $(12-32 \mathrm{wk})$ but during the second year the males showed lower mortality. Calomys callosus, like Baiomys showed a

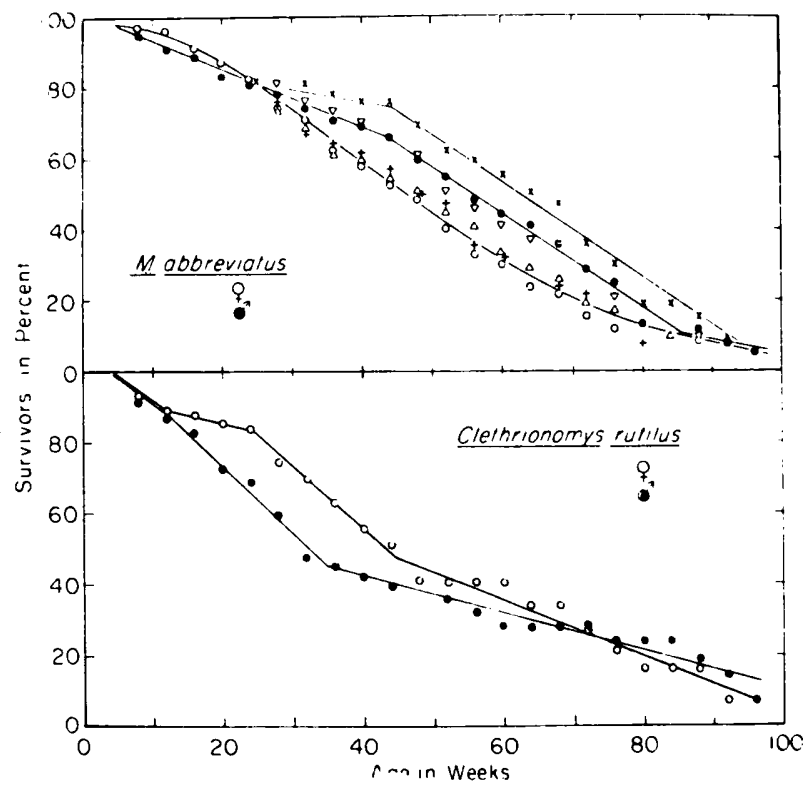

Fig. 4. Survival curves for male and female $(\bullet, 0)$, and paired and unpaired male $(\mathrm{x},+)$ and male + female $(\triangle, \nabla)$ Microtus abbreviatus (O follows $d S / S d t=-6.4 \times$ $\left.\times 10^{-4} t\right)$; male and female $(\bullet, 0)$ Clethrionomys rutilus.

bimodal survival curve with little mortality from 50 to 65 weeks (Fig. 2c). In this case, however, separate grouping of the animals by sex or by pairing did not modify the survival curve.

\section{DISCUSSION}

Patterns of longevity and mortality have been viewed as the resultant of two sets of influences, the one intrinsic relating to genetic characteristics of the population and the other extrinsic relating to various environmental factors (D e e vey, 1947; St r e h l e r, 1960; C o m f or t, 1964). Where losses from random predation or accident dominate, mortality would be constant during most of the life span resulting in ex- 
ponential survival curves $(d S / S d t=-k)$ as described by $\mathrm{D}$ e e ve y (1947) for natural populations of several avian species. Other natural populations appear largely independent of environmental influences during much of their life span until the onset of degenerative changes of aging which follow some intrinsic schedule. The limiting pattern here would be the "skewed rectangular « curve $(t=k \pm \sigma)$ in which mortality is very low through most of the life span but increases rapidly towards the end. This patterns as seen in Dall sheep ( $\mathrm{Murie}$ 1944) is much less common in nature but it may also be present in shrews in which older animals disappear from the population abruptly at about 15 months of age following severe tooth wear (C r ow croft, 1950; $\mathrm{H}$ awes, 1975). This pattern is best known in relation to current human survival which has commonly been represented by the compound exponential (Gompertz) equation, $\log (d S / S d t)=-(a+k t) \quad(\mathrm{C}$ o m for t, 1959; S tr ehler, 1960; Cook, 1972), an empirical relation for which, however, theoretical rationales have been suggested (S a c h e r, 1956, 1960; Sitrehler, 1960).

Because laboratory populations are protected from major hazards encountered in nature they might be expected to follow the same pattern as man. Indeed, the laboratory mouse shows such delayed mortality (M urray \& Hoffman, 1941; Finch, 1969; Russell, 1975; si t o r e r, 1962). However, none of our species showed this behavior with line survival curves being linear over most of the life span and six urves showing some positive curvature (segments with decreased slope). ' This observation follows $\mathrm{C}$ o $\mathrm{m}$ for $\mathrm{t}$ (1957b) who reported that a variety if mammals in zoos including sheep, goats, wolves, voles and cavies were sharacterized by such linear survival curves and suggested that captivity may impose stresses or hazards that increase mortality.

Although the laboratory environments are free of some hazards, dayto-day contact with man or with other animals, even of their own species, is often stressful to captive wild species. Thus, B u ch a lcz y k (1970) found a median life span of 20 months for successful breeding pairs of bank voles (Clethrionomys glareolus) but of only 7 months for animals housed communally. This effect is similar to our experience with Baiomys in which losses in the non-reproducing group were at 3 times the rate of the successful breeding pairs. Beyond such behavioral influences, conditions of caging, diet, temperature, radiation and risk of disease can modify survival in susceptible species. Accordingly, differences in rodent survival under equivalent conditions may be viewed as differing degrees of adjustment to or suitability for captivity. The carnivorous grasshopper mouse, Onychomys, in which an unselected 
population taken from nature showed lower mortality than do inbred strains of white mice and rats (O'F a r r e ll, 1975) may be thought of as "preadapted « for captivity. In addition, longer life spans might be expected in a maintained population since, to the degree that longevity is heritable, the composition of the population should shift progressively towards longer-lived individuals. Store $\mathrm{r}$ (1966) has estimated the "heritability " of longevity for laboratory mice as 0.36 in females and 0.21 in males. By contrast, in natural populations where most individuals die young, to the degree that longevity is inversely related to early maturation, the composition of the population might be expected to shift progressively towards shorter-lived individuals.

In comparing survival in various captive species a simple mathematical expression for these curves would be useful. Linear survival curves are easily characterized $\left(d S / S_{0} d t=-k\right)$ but a relationship involving mortality increases with age, it may be noted that for the simplest function that might be proposed, $(d S / S d t=-k t), S$ is closely linear in $t$ through the middle portion of the survival curve $\left(80-30 \% S_{0}\right.$ ) (L e s l i e \& R a n s o m, 1940). Furthermore, recognizing that the onset of mortality may be advanced or deferred by external circumstances with displacement of the survival curves on the time axis, we may propose an effective live span, $t+t^{\circ}$, for the actual life span, $t$. Figure $5 \mathrm{~A}$ fits this relation to three examples from the genus Microtus, M. o. macfarlani, $M$. o. operarius and $M$. agrestis (L e sli e \& R a n som, 1940) with $t^{\circ}=12$, 0 and -8 , respectively. Constants for these and other curves are given in Table 5. Com fort's (1957b) curve for $M$. orcadensis with $t^{\circ}=4$ and $k=5.8$ is close to ours for $M$. pennsylvanicus, $M$. o. operarius and $M$. $a b$ breviatus, all of which show lower mortality than $M$. o. macfarlani and M. agrestis $\left(T_{50}=50 \mathrm{vs} 35 \mathrm{wk}\right)$. However in a later paper, Les li e et al. (1955) reports finding twice the mean life span for a subsequent population of $M$. agrestis. A similar but lesser difference was noted for earlier (1942) and later (1955) groups of $M$. orcadensis, the later value being almost twice that of $\mathrm{Comfort}$ (1957b). Leslie et al. (1955) suggest »differences in vitality between the two strains" »improved methods of feeding and housing " and "unconscious selection in favor of older-living animals" as possible explanations of these differences. W $\epsilon$ may note that we are currently observing comparable longevity $\left(t_{50}=98\right.$ wk) in another microtine, $M$. xanthognathus, the yellow-cheeked vole.

Even though a linear increase in mortality provides an effective description of survival this may be an approximation since careful examination of data as either survival or mortality curves often suggests a step function rather than a continuous change. These effects are shown in Figure 6 which gives mortality curves for all taxa. Although mortali- 


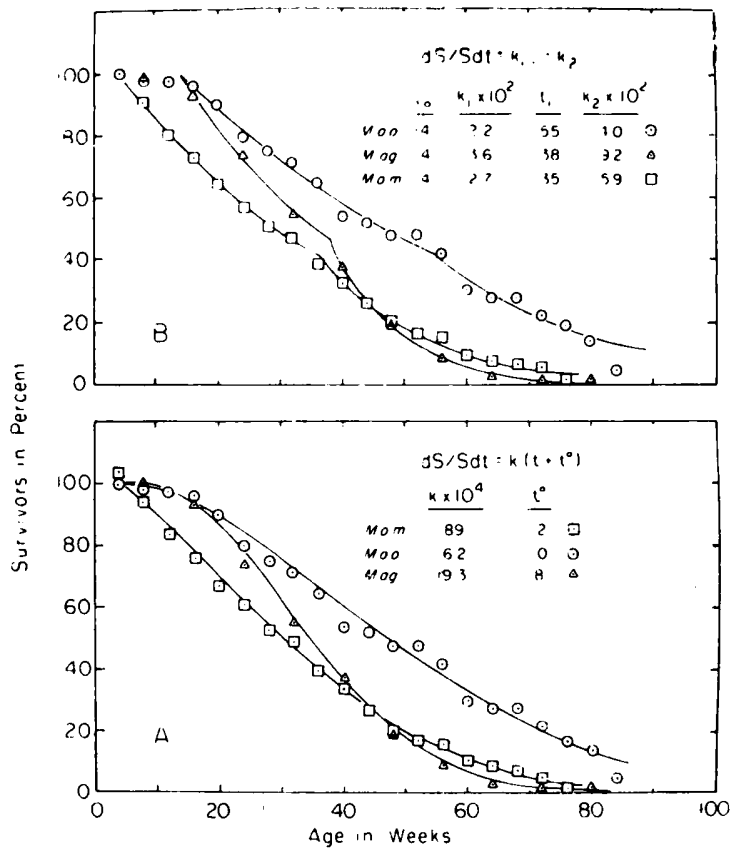

Fig. 5. Survival curves for Microtus agrestis (L e slie \& R a n s o m, 1940), $M$. oeconomus macfarlani, and $M$. o. operarius fitted (A) as $d S / S d t=-k\left(t+t^{\circ}\right)$ or 2 ln $S / S_{\mathrm{o}}=-k t\left(t+t^{\circ}\right)^{2}$; and (B) as $d S / S d t=-k_{1},=-k_{2}$ or $\ln S / S_{\mathrm{o}}=-k_{1} t,=-k_{2} t$.

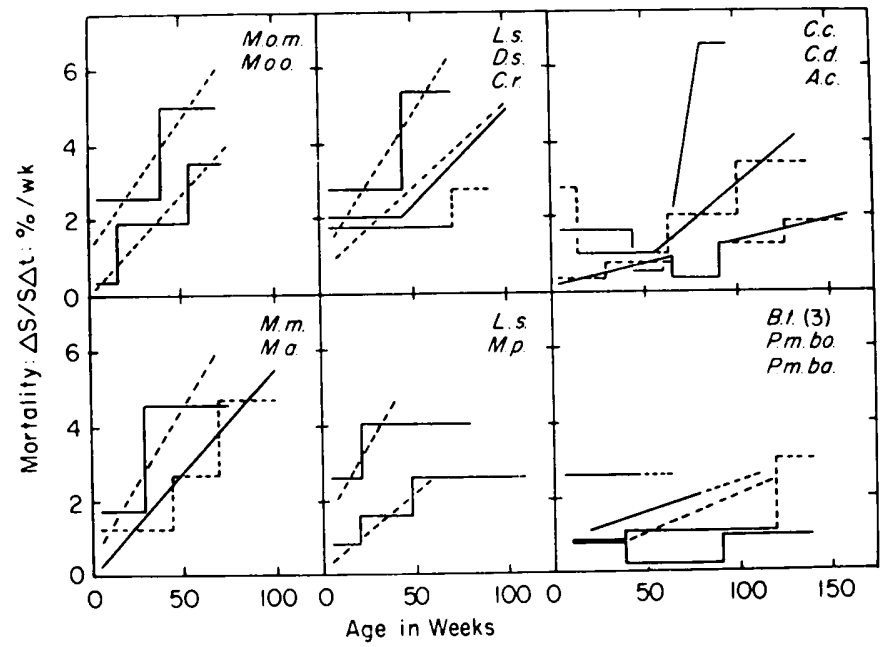

Fig. 6. Mortality $(\Delta S / S \Delta t)$ in relation to age for all taxa. Oblique curves wert fitted to least square deviations. Data favors "solid" configuration. For species coding refer to Table 1 . 
ty curves are more sensitive indices of change than are survival curves, the large dispersion of values often obscures the trends. However, in most cases the use of moving-three averages has smoothed the data sufficiently without blurring any steps. Such step changes could be in keeping with the phasic nature of mortality in which deaths during successive periods are characterized by specific pathologies as especially well documented in man ( $\mathrm{t} \mathrm{trehler,1975).} \mathrm{S} \mathrm{tor} \mathrm{er} \mathrm{(1966)} \mathrm{reported}$ such bimodal distributions of survival associated with specific pathologies in four strains of white mice but in 40 other groups (sex and strain) survival times were »reasonably normally distributed «. Figure 5B compares the same three Microtus as fitted by two logarithmic mortality phases. Although the fit is good this is a much less economical description since two time plus two rate constants are required and so is correspondingly less useful for general comparisons of species.

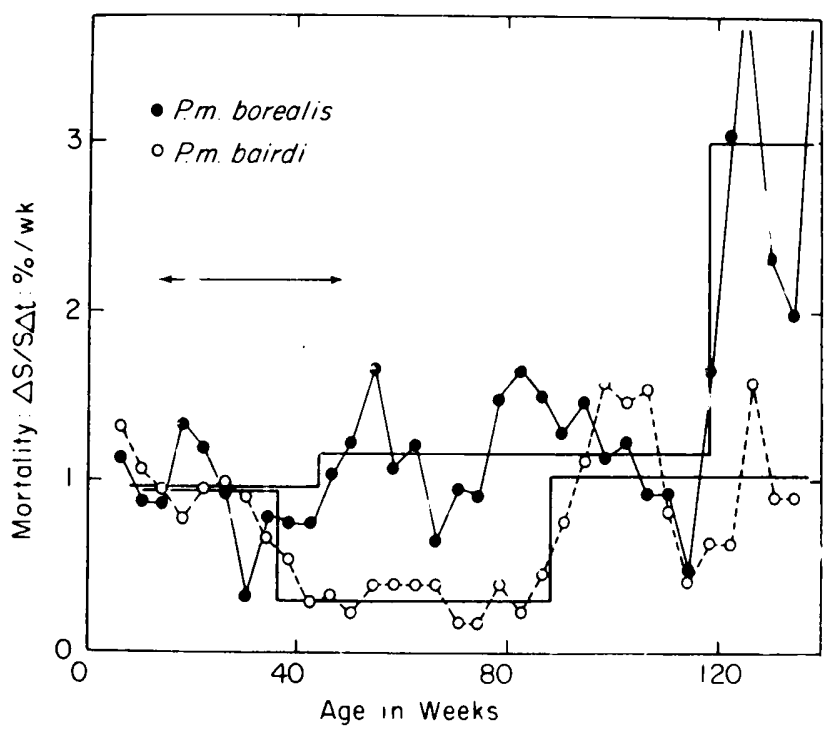

Fig. 7. Mortality as a function of age in 2 subspecies of Peromyscus maniculatus. Points are moving-3 averages. Arrows show period of arrested growth in $P . m$. bairdii.

During the first 120 weeks $P . m$. borealis maintained a steady mean mortality at $1.1 \% / \mathrm{wk}$ with values cycling between 0.5 and $1.6 \% / \mathrm{wk}$ (Fig. 7). Although P. m. bairdii began in this same manner, after 36 weeks mortality fell to a very low value $(0.35 \% / \mathrm{wk})$ which was maintained during the succeeding 50 weeks at which time it increased to the previous level $(1.0 \% / \mathrm{wk})$. This unusual behavior might be viewed as merely an accentuated bimodal distribution of deaths. However in eom- 
paring other aspects of these two subspecies we find that $P . m$. bairdii also contrasts in exhibiting arrested growth during an extended period between 15 and 50 weeks of age (M o r r is o $\mathrm{n}$ et al., 1943). This dietary effect has been considered the only successful example of experimental deferral of aging ( $\mathrm{Com} f$ or $\mathrm{t}, 1964)$ so the association of delayed growth and delayed mortality in another species is of much interest. Between these two subspecies, $P$. m. bairdii has also shown an unusual metabolic lability associated with an alarm response ( $R$ os e $n$ mann \& M or ris o $\mathrm{n}, 1975)$.

In comparing survival curves it was a matter of some surprise that the inland $M$. o. macfarlani and $M$. miurus showed considerably higher

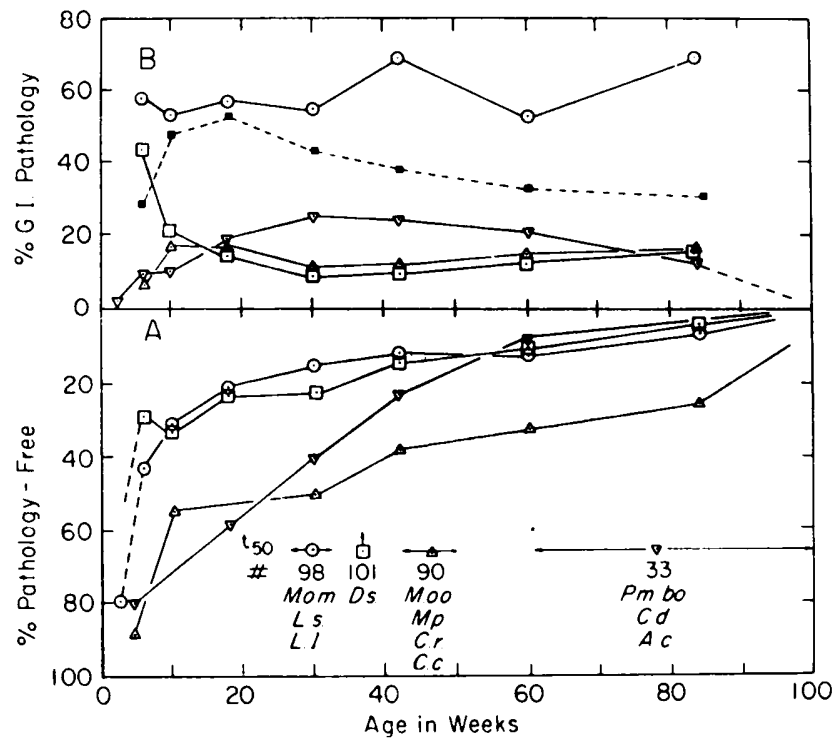

Fig. 8. Pathological findings in relation to age. Rodents are grouped by median life span as indicated with the number of necropsies shown below. "Pathology-free" means nothing found in necropsy. Closed squares compare incidence of respiratory pathology in Dicrostonyx. All points are moving-3 averages.

mortality than their coastal and insular close relatives, $M$. operarius and M. abbreviatus. A similar difference was seen between the two Lemmus and the Dicrostonyx. However, necropsy data (Table 2) revealed some interesting correlations between this higher mortality and the incidence of pathology. These are summarized in Figure 8 which divides the species into groups according to longevity and compares the fraction of individuals in which no pathology was found against age. The earlier incidence of overt pathology in the lemmings and M. o. macfarlani is clearly 
seen. Figure 8 also compares GI pathology, largely fatty livers, and among the 4 groups the higher incidence in Lemmus and M. o. macfarlani is notable. M. o. macfarlani also showed some incidence of renal lipidosis not seen in the other species. This hepatic and renal lipidosis probably reflects the diet in captivity since more carbohydrate and fat was provided than is available to microtines in nature but the differential susceptibility of certain species or subspecies is still not explained. Fin ch (1969) maintained retired male C57B1/6J mouse breeders from the Jackson Laboratory and found an increased average life span as compared to the parent institution (122 vs. $104 \mathrm{wk}$ ). His only noted difference in handling was a reduction in the fat content of the diet from $12 \%$ to $4.3 \%$.

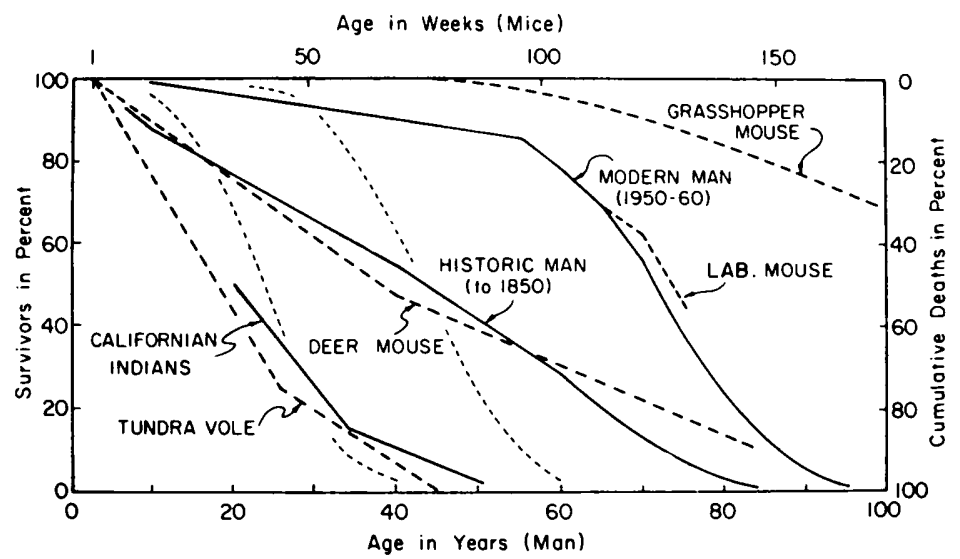

Fig. 9. Comparison of human and rodent survival curves. Soild curves: modern and historic man from Strehler (1975) and Californian Indians from Cook (1972); dashed curves; grasshopper mouse (Onychomys leucogaster) from O'F a r r ell (1975), deer mouse (Peromyscus maniculatus borealis) and tundra vole (Microtus oeconomus macfarlani) from this study, and laboratory mouse $\left(\mathrm{C}^{5} 7 \mathrm{Bl} 6 \mathrm{~J} \mathrm{O}^{*}\right)$ from $\mathrm{Finch}$ (1969). The latter is one of the longer-lived strains of laboratory mouse exceeding other strains by as much as 3-fold (M u r a y \& $\mathrm{H}$ of f m a n, 1941; S tor er, 1966). Survival curves for shorter-lived strains of laboratory mouse correspond to the curves for neither man nor wild mice (dotted curves abovel.

The increased longevity seen in rats under restriced diet is also accompanied by a deferal of pathological changes (M c C a y et al., 1943). O'F a r rell (1975) has reported a similar picture in grasshopper mice, Onychomys leucogaster, with $95 \%$ survival through the first two years followed by increasing mortality during the next two years (median $=3.9$ yr) accompanied by a high incidence of pathological lesions not seen in younger individuals. In long-lived laboratory mouse strains mortality 
stays at a lower level with $80 \%$ survival through the first two years, but increases rapidly in the third year (median $=2.5 \mathrm{yr}$ ) during which $\mathrm{F}$ in $\mathrm{ch}$ (1969) observed a substantial incidence of postmortem pathology not seen during the earlier period. B a r n e t $t$ et al. (1974) also noted very limited pathology in two year old captive house mice.

Com for t (1964) commented on the resemblence of survival curves for captive mammals to some earlier human survival curves and it is possible to compare ranges of curves for mice and men. Thus, Figure 9 keys together survival curves for laboratory mice and modern man representing a scaling difference of $1 \mathrm{mo}: 2.5 \mathrm{yr}$ or $1: 20$ between mice and men. Curves for the deer mouse and »historic" man, and for the tundra vole and Californian indians then correspond respectively in both position (rate) and shape. However, in this representation there is no human analogue for the grasshopper mouse whose "longer " life span may present a goal for "future " man as projected by S tre hl e r (1975). These parallels are interesting and possibly significant in reflecting similarities in mortality and aging but we cannot be sure that differences in various adapted species really correspond to different responses to environment in a single species.

\section{REFERENCES}

1. B a rnett S. A., Munro K. M. H. \& S toddart R. C., 1974: Growth and pathology of aged house mice. Exp. Geront., 9: 275-279.

2. Buchalczyk A., 1970: Reproduction, mortality and longevity of the bank vole under laboratory conditions. Acta theriol., 15: 153-175.

3. Comfort A., 1957a: The biological approach to the comparative study of aging. [In: Ciba Found. Coll. on Aging, G. E. Wolstenholme \& C. M. O'Connor, eds.], 3: 2-19 Little, Brown and Co.

4. Com fort A., 1957a: Survival curves of mammals in captivity. Proc. Zool. Soc., Lond., 128: 349-363.

5. Comfort A., 1959: Natural aging and the effect of radiation. Radiation Res. Supplement, 1: 216-234.

6. Comfort A., 1964: Aging: The Biology of Senescence. Holt, Rinehart and Winston: $1-365$. New York.

7. Cook S. F., 1972: Aging of and in populations. Pp. 581-606, In: "Developmental Physiology and Aging" (P. S. Timiras, ed.), MacMillan: 1-692. New York.

8. C r ow c r of t P., 1950:

9. Deevey E. S., 1947: Life tables for natural populations of animals. Quart. Rev. Biol., 22: 283-314.

10. Dieterich R. A., 1974: Northern exotic animals as models for human disease. J. Amer. Vet. Med. Assoc., 164: 695-696.

11. Dieterich R. A., Morrison P. R. \& Preston D. J., 1973: Comparative organ weights for 8 standardized wild rodent species. Lab. Anim. Sci., 23: $575-581$. 
12. F i n c h C. E., 1969: Cellular activities during aging in mammals. $\mathrm{Ph}$. D. Thesis, Rockefeller Univ.: 1-200. New York.

13. French N. R., Maza B. G. \& A s chwanden A. P., 1967: Lifespans of Dipodomys and Perognathus in the desert. J. Mammal., 48: 537-558.

14. Galster W. A. \& Mor ris on P. R., 1974: Carbohydrate reserves of wild rodents from different latitudes. Comp. Biochem. Physiol., 50A: 153-157.

15. H a de $\mathrm{s}$ M., 1975: Life history strategy in two species of shrews. Ph. D. Thesis, Univ. British Columbia, Vancouver.

16. Les li e P. H. \& R a n S o m R. M., 1940: The mortality, fertility and rate of natural increase of the vole (Microtus agrestis) as observed in the laboratory. J. Anim. Ecol., 9: 27-52.

17. Leslie P. H., Te nner J. S., Vizos o M. \& Chit t y H., 1955: The longevity and fertility of the Orkney vole, Microtus orcadensis as observed in the laboratory. Proc. Soc. London, 125: 115-125.

18. Manning T. H., 1954: Remarks on the reproduction, sex ratio, and life existancy of the varying lemming, Dicrostonyx groenlandicus, in nature and captivity. Arctic, 7: $36-48$.

19. M c C a y C. M., Sperling L. S. \& B arnes L. L., 1943: Growth, aging and chronic diseases and lifespan in the rat. Arch. Biochem., 2: $469-486$.

20. M or $r$ is o n P. R., 1960: A caging arrangement for small mammals. J. Mammal., 41: 283-284.

21. Morrison P. R., 1971: Arctic and alpine rodents as models for biomedical research. Anim. Models for Biomedical Research, 4: 85-91.

22. Morrison P. R., Dieterich R. A. \& Preston D. J., 1976a: Breeding and reproduction of fifteen wild rodents maintained as laboratory colonies. Lab. Anim. Sci., 26: 237-243.

23. Morris on P. R., Dieterich R. A. \& Preston D. J., 1976b: Body growth in 15 wild rodents maintained as laboratory colonies. Growth, in press.

24. M u rie A., 1944: The wolves of Mount McKinley. Fauna Series No. 5, U. S. Dept. Int.: 1-283. Washington, D. C.

25. Murray W. S. \& Hoffman J. G., 1941: Physiological age as a basis for the comparison of strains of mice subject to spontaneous mammary carcinoma. J. Cancer Res., 1: 298-309.

26. Pearson D. P. \& Patt on J. L., 1976: Relationships among South American phyllotine rodents based on chromosomal analysis. J. Mammal., 57: 339-350.

27. O'Farrel T. P. \& Cosgrove G. E., 1975: Longevity and age-related lesions in a laboratory colony of grasshopper mice, Onychomys leucogaster. Amer. Mid. Natural., 94: 241-246.

28. Rosenmann M. \& Morris on P. R., 1974: Physiological characteristics of the alarm reaction in the deer mouse, Peromyscus maniculatus bairdii. Physiol. Zöol., 47: 230-241.

29. Ros enmann M. \& Morrison P. R., 1975: Metabolic response of highland and lowland rodents to simulated high altitude and cold. Comp. Biochem. Physiol., 50A: 523-530.

30. R u s sell E. R., 1975: Lifespan and aging patterns. Pp. 511-519, In: Biology of the Laboratory Mouse" (reprinted) (E. L. Green, ed.): 1-497. Dover, New York.

31. S a cher G. A., 1956: On the statistical nature of mortality, with especial reference to chronic radiation mortality. Radiobiology, 67: 250-257.

32. S a cher G. A., 1959: Relation of lifespan to brain weight and body weight in 
mammals. Pp 115-133, In: Ciba Found. Coll. on the Lifespan of Animals (G. E. W. Wolstenholme and M. O'Connor, eds.), Churchill: 1-220. London.

33. S a cher G. A. \& Staddeldt E. S., 1972: Species differences in the sensitivity of myomorph and sciuromorph rodents to life shortening by chronic gamma radiation. Pp 1042-1047, In: »Radionuclides in Ecosystem * (D. J. Nelson, ed.), Nat. Tech. Info. Serv., Springfield, Va.

34. Store J. B., 1962: Evaluation of radiation response as an index of aging in mice. Radiation Res., 17: 878-902.

35. Store J. B., 1966: Longevity and gross pathology at death in 22 inbred mouse strains. J. Gerontol., 21: 404-409.

36. Strehler B. L., 1960: Fluctuating energy demands as determinants of the death process (a parsimonious theory of the Gompertz Function). Pp 309-314, In: »The Biology of Aging (B. L. Strehler, ed.). Amer. Inst. Biol. Sci.: 1-385. Washington, D. C.,

37. Strehler B. L., 1975: Implications of aging research for society. Fed. Proc., 34: 5-13.

Accepted, March 17, 1977.

Peter MORRISON, Robert DIETERICH i Diane PRESTON

\section{PRZEŻYWALNOSC U 15 GATUNKOW I PODGATUNKOW GRYZONI TRZYMANYCH W HODOWLI}

\section{Streszczenie}

Przedstawiono dane o długości życia i śmiertelności 15 dzikożyjących gatunków i podgatunków gryzoni hodowanych w warunkach laboratoryjnych. Są to: Microtus pennsylvanicus tananaensis, $M$. oeconomus macfarlani, M. o. operarius, M. miurus, $M$. abbreviatus, Lemmus lemmus, L. sibiricus trimucronatus, Dicrostonyx stevensoni, Clethrionomys rutilus, Peromyscus maniculatus borealis, P.m. bairdii, Baiomys taylori, Calomys ducilla, C. callosus, Acomys cahirinus (Tabela 1). Śmiertelność gryzoni $w$ pierwszym tygodniu życia wynosi srednio $11 \%$ (0 do $23 \%$ ), a ich śmiertelność $\mathrm{w}$ ciągu pierwszego miesiąca życia równa się $23 \%$ (10 do $38 \%$ ). Przeciętna długośc życia dla zwierząt odjętych od matki w wieku 1 miesiąca trwa średnio 50 tygodni i najniższa jest u L.l. - 25 tygodni a najwyższa u A.c. 108 tygodni. Wskaźnik ten waha się u przedstawicieli Microtinae od 25 do 40 tygodni, a u Cricetinae od 44 do 105 tygodni, za wyjątkiem B.t. (Ryc. 6). Krzywa obrazująca przeżywanie jest dla większości Microtinae liniowa lub skośna (ds/dt= $=-k)$ a nie logarytmiczna $(d S / S d t=-k)$ czy też zgodna z równaniem Gompertza $(\log d S / S d t=A=k t)$ i może być charakteryzowana przez dwie stałe opisujące liniowy wzrost śmiertelności w czasie: $d S / S d t=-k\left(t=t^{\circ}\right)$ lub $\ln S / S_{\mathrm{o}}=-k\left(t+t^{\circ}\right)^{2}(\mathrm{Ta}-$ bele 2,3 , Ryc. 1-5). Niekojarzone $B$. $t$. cechują się logarytmiczną krzywą przeżywania, która po połączeniu tych zwierząt w rozradzające się pary zmienia swój kształt i poziom (Ryc. 3). Inne gatunki wykazują znacznie mniejszą zależność pomiędzy przeżywalnością a płcią czy też trzymaniem w grupach. Duża śmiertelność młodych M.o.m., L.l. i L.s. skorelowana była $\mathrm{z}$ objawami otluszczenia wątroby i u D.s. chorobami układu oddechowego (Tabele 2, 3, Ryc. 7, 8). 